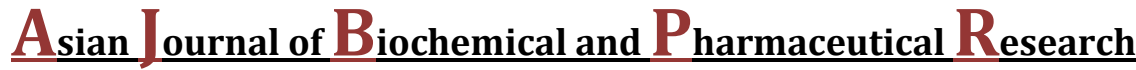

\section{Electrochemical Behaviour of SS18/8 Bracket in Presence of Limcee Tablet with Artificial Saliva}

\author{
A. Anandan ${ }^{1 *}$, Susai Rajendran ${ }^{2}$, J. Sathiyabama ${ }^{3}$, D. Sathiyaraj ${ }^{1}$ and Abdulhameed Al-Hashem ${ }^{4}$ \\ ${ }^{* 1}$ SKV Higher Secondary School, Department of Chemistry, Kandampalayam-637201, India \\ ${ }^{2}$ Corrosion Research Centre, Department of Chemistry, St Antony's College of Arts and Sciences for women, Dindigul-624005, India \\ ${ }^{3} \mathrm{PG}$ and Research Department of Chemistry, GTN Arts College, Dindigul - 624005, India \\ ${ }^{4}$ Petroleum Research Centre, Kuwait Institute for Scientific Research, Kuwait
}

Received: 25 September 2018; Revised: 05 October 2018; Accepted: 08 October 2018

\begin{abstract}
The effects of Limcee on corrosion of the SS18/8 bracket in artificial saliva have been studied by polarisation and AC-impedance spectra. These analysis indicates corrosion resistance of SS18/8 bracket increases incidence of Limcee (300ppm) with artificial saliva due to increases in Rpol (Linear polarisation Resistance), Rt (Charge transfer resistance) and decreases in Cdl (Double layer capacitance), Icorr (corrosion current). Increase inhibition efficiency of SS18/8 bracket is due to incidence of components of Limcee tablet. Electrochemical studies reveal Limcee tablet (cathodic) effective corrosion inhibitor on SS18/8 bracket with artificial saliva. Hence these analysis recommended that people implies with orthodontics made of SS18/8 need not hesitate, to take Limcee tablet oraly.
\end{abstract}

Keywords: SS18/8 bracket, Limcee, Artificial Saliva, Polarisation and AC-impedance spectra

\section{INTRODUCTION:}

Used in more number of application stainless steel is the important metals such as orthodontics (archwire, bands, brackets). The different type of toothpastes using the course of treatments may have corrosion on these metals (orthodontics). To evaluate the corrosion resistance of SS316L alloy in AS (Artificial Saliva) in presence of sparkle fresh toothpastes by using polarisation, ACimpedance, SEM (EDAX), UV-visible and fluorescence spectra. Incidence of sparkle fresh toothpastes, increases in corrosion resistance of the SS316L alloy [1] stainless steel (orthodontics) have been worldwide used dentistry [2] the addition of Mo (molybdenum) has increased the corrosion resistance of SS alloy for dental materials which contain $\mathrm{Cr}-18 \%$ and $\mathrm{Ni}-8 \%$ weight.
The influence of chloride on corrosion resistance SS alloy enhanced (SS316L alloy) [3] C-glucose on SS316L and 22carat gold alloy [4]. The archwire based on the Ni-Ti SMAs is introduced in the orthodontics therapy. Because of its shape memory behaviour as well as corrosion resistance and mechanical properties [5]. Katic et.al., to evaluate corrosion rate of orthodontic (Ni-Ti) wires in artificial saliva. The corrosion resistance increases in the followings: $\mathrm{Rh}-$ $\mathrm{NiTi}<\mathrm{NiTi}<\mathrm{N}-\mathrm{NiTi}[6]$.

Influence of protein on $\mathrm{Ni}-\mathrm{Ti}$ and $\mathrm{SS}$ alloy with copper interlayer with artificial saliva. Protein concentration increases, corrosion rate decreases confirmed by polarisation and SEM analysis [7]. To evaluate characteristic of the corrosion behaviour and compare two types (Ti-6Al-4V, Ti-10Mo-4Zr) of titanium 
alloys with MAS containing Lactic acid and Hydrogen peroxide by using electrochemical impedance spectra [EIS], open circuit potential (OCP), Linear Sweep Voltammetry (LSV). The result of the work that titanium alloys has high corrosion resistance [8]. Rylska et.al., corrosive properties and structure of the Co-Cr base orthodontic alloy by soft material with sinterization. The polarisation, SEM analyses suggest more corrosion resistance of sintered element [9]. To investigation of corrosion resistance of $\mathrm{Ni}-\mathrm{Ti}$ orthodontics in artificial saliva have been studied by polarisation and SEM analysis [10]. R.J. Rathish et.al., to evaluated corrosion behaviour of SS316L dental wire in artificial sweet [11]. Corrosion resistance of three (SS 316L, MS-Zn, MS) dental wires with artificial saliva in D-glucose measured by polarisation and AC-Impedance spectra.

It observed from the result corrosion rate decreases in following order: $\mathrm{MS}>\mathrm{MS}-\mathrm{Zn}>$ SS316L [12] electral [13] in spirulina corrosion rate decreasing order: $\mathrm{MS}-\mathrm{Zn}>\mathrm{MS}$ $>$ SS316L [14]. This research work is undertaken to evaluate the electrochemical behaviour of SS18/8 bracket in presence of Limcee with artificial saliva by using polarisation and AC-impedance spectra.

\section{METHODS AND MATERIALS:}

\section{Potentiodynamic Polarization method:}

These studies were carried out in CHIelectrochemical work station with impedance model-660A. Polarization was providing with iR compensation facility. Electrochemical analyzer contains three electrodes assembly (Fig.1). The working electrode was SS18/8 bracket; SCE was reference electrode; Platinum was counter electrode. From this study, corrosion data such as Rpol (linear polarization resistance), Ecorr (corrosion potential), Icorr (corrosion current), Tafel slopes anodic (ba), cathodic (bc) were calculated. This study has been used to confirm, formation of defending film formed on (SS18/8) metal surface for the duration of corrosion inhibition process [1519]. If a defending film is formed on the metal surface, increases in Rpol values, decreases in Icorr values.

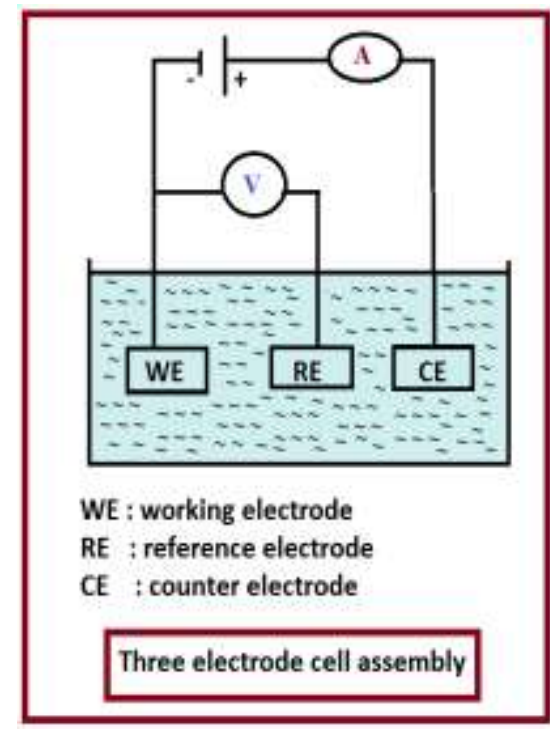

Fig. 1: Three electrodes assembly

\section{AC-impedance method:}

AC-impedance analyzer model (CHI 660A) used to record AC-impedance parameters. This analyzer cell set up, same for polarization spectra. The real and imaginary parts (Z' and Z') of the cell AC-impedance were measured (ohms) for various frequencies. AC-impedance parameters such as, Rt (charge transfer resistance), Cdl (double layer capacitance), Impedance were calculated. If a defending film is formed on the metal surface, increases in Rt values, decreases in Cdl values [15-19]. 
Table: 1 Compositions of Saliva

\begin{tabular}{|c|c|}
\hline Compositions & g/lit \\
\hline $\mathrm{NaCl}$ & 0.4 \\
\hline $\mathrm{KCL}$ & 0.4 \\
\hline $\mathrm{CaCl}_{2} 2 \mathrm{H}_{2} \mathrm{O}$ & 0.906 \\
\hline $\mathrm{NaH}_{2} \mathrm{PO}_{4} .2 \mathrm{H}_{2} \mathrm{O}$ & 0.690 \\
\hline $\mathrm{Na}_{2} \mathrm{~S}_{9} . \mathrm{H}_{2} \mathrm{O}$ & 0.005 \\
\hline $\mathrm{Urea}$ & 1.0 \\
\hline
\end{tabular}

Table: 2 Composition of Tablet-B

\begin{tabular}{|l|l|l|}
\hline \multicolumn{1}{|c|}{ Tablet } & \multicolumn{1}{|c|}{ Compositions } & Represent \\
\hline Limcee- & 1.Ascorbic Acid & Tablet-B \\
$500 \mathrm{mg}$ & 2.Sodium & \\
(Vitamin-C & Ascorbates & \\
Chewable $)$ & & \\
\hline
\end{tabular}

\section{RESULTS AND DISCUSSION:}

\section{Analysis of polarization curves:}

The polarization curve of SS18/8 bracket immersed with artificial saliva in presence of Tablet-B, obtain from polarization analysis shown in Fig.2. The polarisation parameters, Rpol (ohm $\mathrm{cm}^{2}$ ), Ecorr (mV vs SCE), Icorr $\left(\mathrm{A} / \mathrm{cm}^{2}\right)$, Tafel bc and ba slopes ( $\mathrm{mV} /$ decade), are given in Table 3 .

When SS18/8 bracket immersed with AS (Artificial Saliva), the Ecorr (potential) is 373 (mV vs SCE). When Tablet-B (300ppm) added to the system, Ecorr value is shifted to $-506(\mathrm{mV}$ vs $\mathrm{SCE}$ ). These values indicate that cathodic type reaction is inhibited predominantly. That is the cathodic type reaction of SS18/8 bracket dissolution is inhibited by formation of defending film on cathodic site of the metal alloy surface. The active ingredient of the tablet has been adsorbed on SS18/8 bracket surface forming metal complex on cathodic sites. Further, the Rpol value increases from 3352584to $5750444 \mathrm{ohmcm}^{2}$, Icorr value decreases from $1.561 \times 10^{-8}$ to $0.7407 \times 10^{-8} \mathrm{~A} / \mathrm{cm}^{2}$.
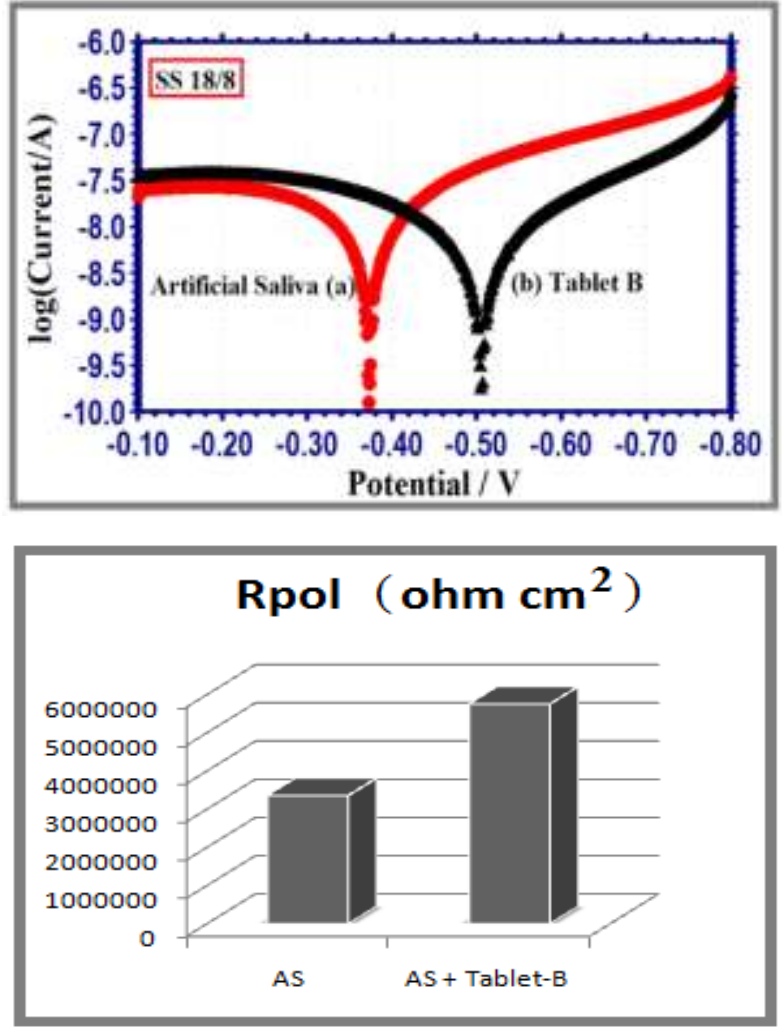

Fig. 2: Polarisation curves (Ecorr) of SS18/8 bracket immersed with Artificial Saliva in absence and presence of Tablet-B: (a) Artificial Saliva (AS); (b) AS + Tablet B (300ppm)

Thus, polarization studies confirm the formation of defending film on SS18/8 bracket surface. The entire these observation lead to the conclusion that in presence of Tablet-B, higher corrosion resistance of SS18/8 bracket. Hence this study leads to the conclusion that populace having orthodontic wires made of SS18/8 bracket need not hesitate, to take Tablet-B. The active ingredient of the tablet has not corroded the SS18/8 bracket. 
Table 3: Corrosion parameters of SS18/8 bracket immersed with Artificial Saliva in absence and presence of Tablet-B

\begin{tabular}{|c|c|c|c|c|c|}
\hline $\begin{array}{c}\text { System } \\
\text { (300 ppm) }\end{array}$ & $\begin{array}{c}\text { Ecorr } \\
\text { mV vs } \\
\text { SCE }\end{array}$ & $\begin{array}{c}\mathbf{b}_{\mathbf{c}} \\
\mathbf{m V} / \\
\text { decade }\end{array}$ & $\begin{array}{c}\mathbf{b}_{\mathbf{a}} \\
\mathbf{m V} / \\
\text { decade }\end{array}$ & $\begin{array}{c}\text { Rpol } \\
\text { ohm cm } \text { cm }^{2}\end{array}$ & $\begin{array}{l}\text { Icorr } \\
\text { A/cm }\end{array}$ \\
\hline AS & -373 & 197 & 309 & 3352584 & $1.561 \times 10^{-8}$ \\
\hline $\mathrm{AS}+$ Tablet-B & -506 & 181 & 213 & 5750444 & $0.7407 \times 10^{-8}$ \\
\hline
\end{tabular}

\section{Analysis of AC-Impedance spectra:}

The AC-Impedance spectra of SS18/8 bracket immersed with artificial saliva in absence and presence of Tablet-B are shown Figs.3,4. The AC-Impedance parameters Rt (charge transfer resistance), Cdl (double layer capacitance) derived from the Nyquist plot (Fig.3) and impedance value derived from Bode plot (Fig.4) given in Table.4.

Table 4: AC-impedance parameters of SS18/8 bracket immersed with Artificial Saliva in absence and incidence of Tablet-B

\begin{tabular}{|c|c|c|c|}
\hline $\begin{array}{c}\text { System } \\
(\mathbf{3 0 0 p p m})\end{array}$ & $\begin{array}{c}\mathbf{R t} \\
\mathbf{o h m} \\
\mathbf{c m}^{2}\end{array}$ & $\begin{array}{c}\mathbf{C d l} \\
\mathbf{F} / \mathbf{c m}^{2} \\
\left(\mathbf{x 1 0} \mathbf{1 0}^{\mathbf{1 0}}\right)\end{array}$ & $\begin{array}{c}\text { Impedance } \\
\mathbf{L o g} \\
(\mathbf{z} / \mathbf{o h m})\end{array}$ \\
\hline $\mathrm{AS}$ & 44851 & 1.1370 & 4.634 \\
\hline AS + Tablet-B & 144700 & 0.3524 & 5.109 \\
\hline
\end{tabular}

It observed that the Tablet-B (300ppm) added to system (artificial saliva), charge transfer resistances (Rt) increases from 44851 to $144700 \mathrm{ohm} \mathrm{cm}^{2}$, double layer capacitances (Cdl) value decreases from $1.137 \times 10^{-10}$ to $0.3524 \times 10^{-10} \mathrm{~F} / \mathrm{cm}^{2}$. The impedance (z/ohm) value increases from 4.634 to 5.109 . This result lead to the conclusion that defending film is formed on SS18/8 bracket surface. The entire these observations lead to the conclusion that presence of Tablet-B higher corrosion resistance of SS18/8 bracket, contact with artificial saliva. Hence AC- impedance spectra lead to the conclusion that populace having SS18/8 bracket need not hesitate, to take Tablet-B. The active ingredient of the tablet has not corroded the orthodontic wires made of SS18/8 bracket.
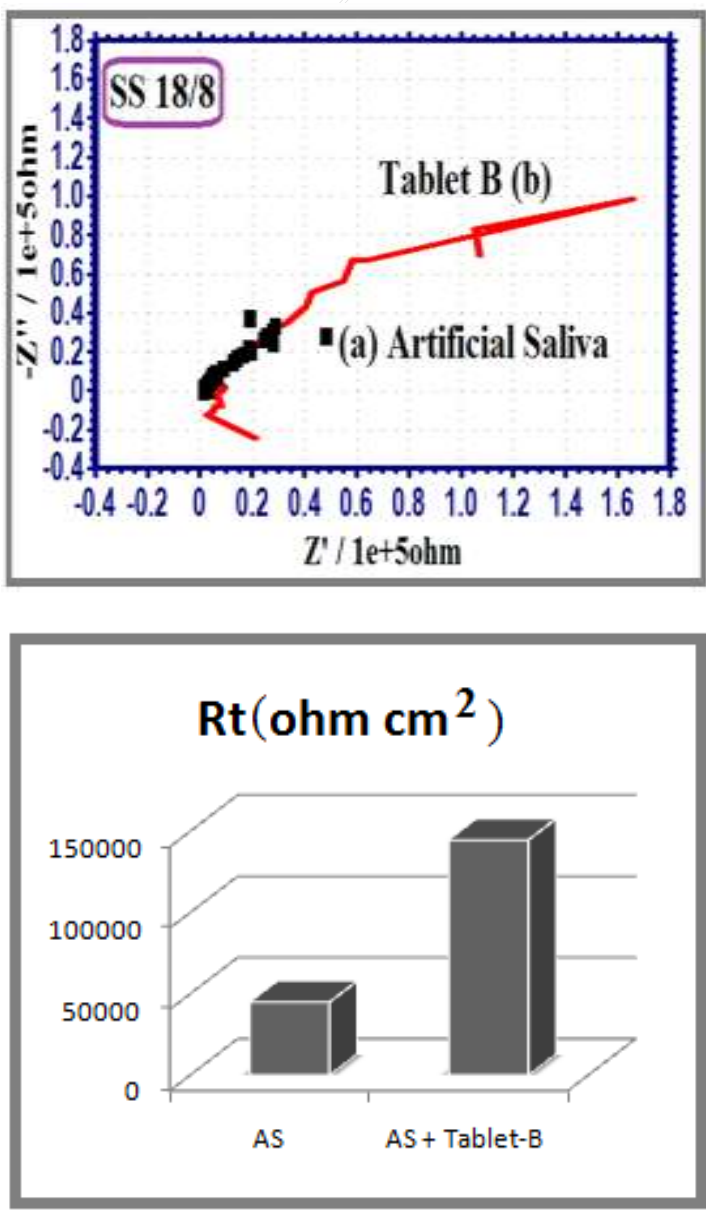

Fig. 3: Nyquist Plots (Cdl) of SS18/8 bracket immersed with Artificial Saliva in absence and presence of Tablet-B 


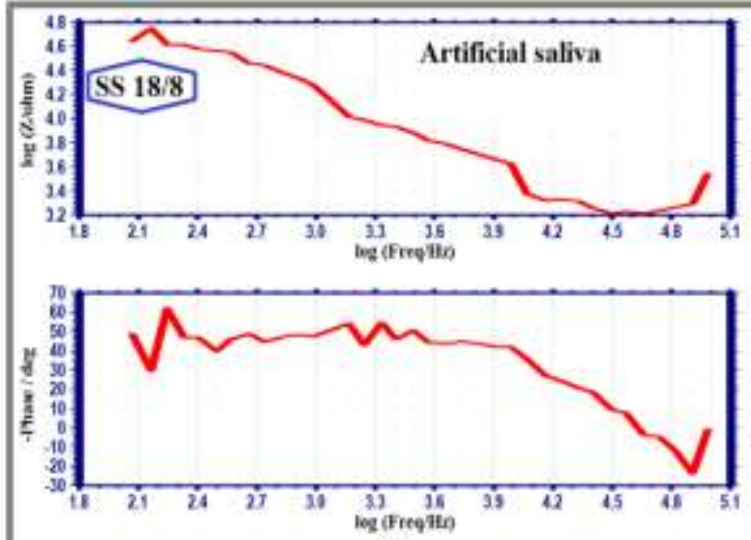

(a)
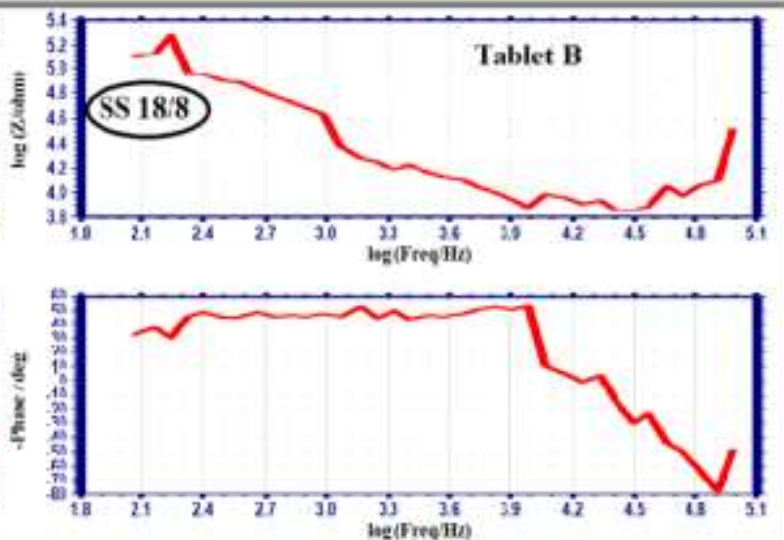

(b)

Fig. 4: Bode Plots (Impedance) of SS18/8 bracket immersed with Artificial Saliva in absence and presence of Tablet-B

\section{CONCLUSION:}

From polarization and AC-Impedance data was concluded that higher corrosion resistance of SS18/8 bracket with artificial saliva in presence of Tablet-B, due to the formation of a defending film (increases in Rpol, Rt and decreases in Icorr, Cdl). Hence electrochemical studies suggest that populace having SS18/8 bracket need not hesitate, to take Tablet-B. The active ingredient of the Tablet-B has not corroded the orthodontic wires made of SS18/8 bracket. Polarization test reveals that Tablet-B system function as cathodic type inhibitor controlling the cathodic reaction.

\section{REFERENCE:}

1. Renita D Souza, Amit Chattree and S. Rajendran, Portugaliae Electrochimica Acta, 2017, 35(6),339-350.

2. J. Mary, S. Rajendran, Portugaliae Electrochimica Acta, 2013, 31(1), 33-40

3. H. Hermawan, D. Ramdan, J. R. P. Djuansjah, INTECH, 2011, 17, 411-430, DOI: $10.5772 / 19033$

4. R. Saranya, S. Rajendran, Der Pharma Chemica, 2017, 9(8), 128-132.
5. F. Miura, M. Mogi, Y. Ohura, H. Hamanaka, American Journal of Orthodontics And Dentofacial Orthopedics, 1986, 90(1), 1-10.

6. V. Katï̈., L. C̈urkovï̈, M. Ujevï̈ Bošnjak, S. Špalj, Materialwissenschaft und Werkstofftechnik, 2014, 45(2), 99105.

7. C. Zhang, X. Sun, X. Hou, Hongmei Li, D. Sun, Int. J. Med. Sci., 2013, 10(8), 1068-1072.

8. J. Loch, H. Krawiec, A. Łukaszczyk, J. Augustyn-Pieniążek, Journal of Achievements in Materials and Manufacturing Engineering, 2016,74(1), 29-36.

9. D. Rylska, G. Sokołowski, B. Konieczny, J. Sokołowski, Journal of Achievements in Materials and Manufacturing Engineering, 2016; 74(2), 60-71.

10. J. K. Liu, I. H. Liu, C. Liu, T. M. Lee, J. L. Jou, Appl. Surf. Sci., 2014, 317, 974981.

11. R. Joseph Rathish, S. Rajendran, J. Lydia Christy, B. Shyamala Devi, S. Johnmary, M. Manivannan, K. Rajam 
and P. Rengan, The Open Corrosion Journal, 2010, 3, 38-44.

12. S. Rajendran, V. Uma, A. Krishnaveni, J. Jeyasundari, B. Shyamaladevi, and M. Maivannan, The Arabian Journal for Science and Engineering, 2009, 34(2c), 147-158.

13. S. Rajendran1, P. Chitradevi, S. Johnmary, Zaštita Materijala, 2010, 51(3), 149-158.

14. S. Rajendran, P. Sumithra, B. Shyamaladevi and J. Jeyasundari, Zastita Materijala, 2009, 50(4), 223226.

15. H. Mohamed Kasim sheit, M. Seeni Mubarak, S. S. Syed Abuthahir and Susai Rajendran, Asian Journal of Biochemical and Pharmaceutical Research, 2017, 1(7), 43-49.
16. N. Schiff, F. Dalard, M. Lissac, European Journal of Orthodontics, 2005, 27(6), 541-549.

17. T. Büyükyılmaz, V. Tangugsorn, B. Ogoard, J. Arrends, J. Ruben, G. Rolla, American Journal of Orthodontics and Dentofacial Orthopedics, 1994, 105, 293-296.

18. T. Kang, S. Y. Huang, J. J. Huang, D.F. Diao, Y. Z. Duan, Journal of Nanoscience and Nanotechnology, 2015, 15(6), 4641-4647.

19. W. Wichai, N. Anuwongnukroh, S. Dechkunakorn, Advanced Materials Research, 1, 2014, 560-565. https://www.scientific.net/AMR.884885.560

\section{Corresponding Author: A. ANANDAN, Director, SKV Hr Sec School, Namakkal,}

Tamilnadu, INDIA. 